\title{
The importance of high-quality data and analytics during the pandemic
}

\author{
Maria Petrescu ${ }^{1,2} \cdot$ Anjala S. Krishen ${ }^{3}$
}

Published online: 3 June 2020

๑) Springer Nature Limited 2020

Let them eat cake! During the COVID-19 pandemic, vast amounts of bread might be stuck on the supply chain or be thrown away to pigs. Actually, multiple pigs end up being thrown away, just like thousands of gallons of milk, eggs, and vegetables left to rot on the fields. During this unfortunate wastage caused by the pandemic, grocery stores still experience shortages (Newman and Bunge 2020; YaffeBellany and Corkery 2020). Even though it has been exacerbated and enhanced by the epidemic, this logistics and supply chain crisis has been a long time in the making, as is noted by both business researchers and practitioners. Centralization of supply chain operations and information, lack of data integration and aggregation, and societal, regulatory and systemic constraints have all led to food wastage and supply chain issues in the industry (Gruber et al. 2016; Shanker and Mulvany 2018).

In tandem, the crisis emphasizes the numerous problems that appear in public and private systems in relation to data reporting, integration, aggregation, and analytic systems. Scientists are faced with analyzing which COVID-19 public policy strategy worked best in order to formulate future measures (Gibney 2020). In this process, they are contending with problems related to compiling data, merging distinct reporting systems and methods among states, regions, and countries, and standardizing information collected by different teams. Researchers and analytics experts have limited access to quality data, require time to calibrate existing models, and might face pushback from decision-makers due

Maria Petrescu

maria.petrescu@icn-artem.com

Anjala S. Krishen

Anjala.krishen@unlv.edu

1 ICN Business School Artem, CEREFIGE Laboratoire, Nancy, France

2 Colorado State University Global, Aurora, CO, USA

3 Lee Business School, University of Nevada, Las Vegas, NV, USA to outcome bias, or the tendency to overweight observed outcomes (Dillon et al. 2016).

The importance of high-quality data and analytics throughout the back-end and front-end organizational processes, including the supply chain and the customer relationship management process, as the food industry demonstrates, is greater than ever (Peltier et al. 2013). Previous literature cites the importance of information sharing and collaboration among stakeholders to generate collective insights and emphasizes the role of digital technology to bridge circularity holes in the supply chain (Ciulli et al. 2019; Gadde and Amani 2016). To lower food wastage in the network, stakeholders must collaborate to increase societal engagement, awareness, and knowledge; information sharing with quality data can ultimately lead to greater sustainability and sustainable innovation levels (Bonadonna et al. 2019; Crittenden et al. 2011; Devin and Richards 2018; Sheth et al. 2011; Varadarajan 2017). At times like these, high quality data and analytics can enable knowledge-based, creative, innovative, and transformative solutions.

\section{References}

Bonadonna, A., A. Matozzo, C. Giachino, et al. 2019. Farmer behavior and perception regarding food waste and unsold food. British Food Journal 121 (1): 89-103. https://doi.org/10.1108/ BFJ-12-2017-0727.

Ciulli, F., A. Kolk, and S. Boe-Lillegraven. 2019. Circularity brokers: Digital platform organizations and waste recovery in food supply chains. Journal of Business Ethics. https://doi.org/10.1007/s1055 1-019-04160-5.

Crittenden, V.L., W.F. Crittenden, L.K. Ferrell, Ferrell O.C. Ferrell, and C.C. Pinney. 2011. Market-oriented sustainability: A conceptual framework and propositions. Journal of the Academy of Marketing Science 39 (1): 71-85. https://doi.org/10.1007/s1174 7-010-0217-2.

Dillon, R.L., C.H. Tinsley, P.M. Madsen, and E.W. Rogers. 2016. Improving recognition of near-miss events through organizational repair of the outcome bias. Journal of Management 42 (3): 671-697. 
Devin, B., and C. Richards. 2018. Food waste, power, and corporate social responsibility in the australian food supply chain. Journal of Business Ethics 150 (1): 199-210. https://doi.org/10.1007/s1055 1-016-3181-z.

Gadde, L.E., and P. Amani. 2016. Food supply in a network context: An alternative framing and managerial consequences in efforts to prevent food waste. British Food Journal 118 (6): 1407-1421. https://doi.org/10.1108/BFJ-10-2015-0401.

Gibney, E. 2020. Whose coronavirus strategy worked best? Scientists hunt most effective policies. Nature 581 (7806): 15-16. https:// doi.org/10.1038/d41586-020-01248-1.

Gruber, V., C. Holweg, and C. Teller. 2016. What a waste! Exploring the human reality of food waste from the store manager's perspective. Journal of Public Policy \& Marketing 35 (1): 3-25. https:// doi.org/10.1509/jppm.14.095.

Newman, J., and J. Bunge. 2020. Farmers dump milk, break eggs as coronavirus restaurant closings destroy demand. The Wall Street Journal. https://www.wsj.com/articles/farmers-deal-with-glut-offood-as-coronavirus-closesrestaurants-11586439722. Accessed 19 May.

Peltier, J., D. Zahay, and A.S. Krishen. 2013. A hierarchical IMC data integration and measurement framework and its impact on CRM system quality and customer performance. Journal of Marketing Analytics 1 (1): 32-48.

Shanker, D., and L. Mulvany. 2018. America is drowning in milk nobody wants. Bloomberg, 1-6. https://www.bloomberg.com/ news/articles/2018-10-17/america-is-drowning-in-milk-nobod y-wants. Accessed 19 May.

Sheth, J.N., N.K. Sethia, and S. Srinivas. 2011. Mindful consumption: A customer-centric approach to sustainability. Journal of the Academy of Marketing Science 39 (1): 21-39. https://doi. org/10.1007/s11747-010-0216-3.

Varadarajan, R. 2017. Innovating for sustainability: A framework for sustainable innovations and a model of sustainable innovations orientation. Journal of the Academy of Marketing Science 45 (1): 14-36. https://doi.org/10.1007/s11747-015-0461-6.
Yaffe-Bellany, B.D., and M. Corkery. 2020. Dumped milk, smashed eggs, plowed vegetables: Food waste of the pandemic. The New York Times. https://www.nytimes.com/2020/04/11/business/coron avirus-destroying-food.html. Accessed 19 May.

Publisher's Note Springer Nature remains neutral with regard to jurisdictional claims in published maps and institutional affiliations.

Maria Petrescu is an Associate Professor of Marketing at ICN Business, School Artem, Nancy, France. Her main research areas include marketing analytics and digital marketing. She has published articles in journals such as Psychology \& Marketing, the Journal of Marketing Management, Public Management Review, Journal of Product and Brand Management, the Journal of Retailing and Consumer Services, and the Journal of Internet Commerce.

Anjala S. Krishen is a Professor of Marketing and International Business and Director of MBA Programs at University of Nevada, Las Vegas, has a B.S. in Electrical Engineering from Rice University, and an M.S. Marketing, MBA, and Ph.D. from Virginia Tech. She held management positions for 13 years before pursuing a doctorate. As of 2019, she has published over 50 peer-reviewed journal papers in journals including Journal of Business Research, Psychology \& Marketing, Information \& Management, European Journal of Marketing, Journal of Travel \& Tourism Marketing, and Journal of Marketing Education. In 2016, she gave a TEDx talk (at UNR) titled "Opposition: The light outside of the dark box," and a UNLV Creates speech entitled "Consuming to Creating, Watching to Doing, Seeing to Being." To date, she has completed over 55 marathons, seven ultramarathons, three 100 milers, and has a black belt in Taekwondo. 